\author{
M. Yeskeyeva ${ }^{1}$, G. Kortabayeva ${ }^{2 *}$ \\ ${ }^{1}$ L.N. Gumilyov Eurasian National University, Kazakstan, Nur-Sultan \\ ${ }^{2}$ Al-Farabi Kazakh National University, Kazakhstan, Almaty \\ *e-mail: turki_alemi@mail.ru
}

\title{
THE IDEA OF “TENGRISM" IN TURKIC PROVERBS
}

\begin{abstract}
Although the Turkic people have the same origin, their beliefs do not coincide, therefore it is difficult to study the religious beliefs of the Turkic people. The religious and theological paradigm of Turkology is very extensive. The strategic direction of theological Turkology is the scientific analysis of the historical and political factors of the adoption of a particular religion by the Turkic people of different religions, clarification of the system of common values of the Turks of at least one religious class, grouping them according to genealogical and linguistic similarities. The paper aims to identify traces of the idea of "Tengrism" in the worldview of modern Turks through the content of Turkic proverbs and sayings. The continuity and interaction of the common Turkic mythological and religious worldviews are differentiated on the basis of a single paremiological meaning and semantic range of keywords. It is defined that the attributes of the idea of Tengrism in the language of Turkic written monuments of the VI-IX centuries are also reflected in the content of Proverbs and sayings of modern Turkic peoples who profess Islam (Kazakh, Karakalpak, Kyrgyz, Bashkir, and Tatar). The synonymic meaning and common symbolic meanings of the theonyms "Tengir", "Allah", "God", which form the dominant words in Proverbs and sayings, are analyzed. The influence of the semantic features of the supporting/dominant word on the paremiological meaning is considered. One of Turkic Studies' topical problems is the study of the continuity of the religion of "Tengrism" and Islam through language units, which form the basis of the religious and mythological faith of the Turkic peoples.
\end{abstract}

Key words: paremiology, old Turkic manuscripts, Turkic languages, theonym, the idea of Tengrism.

$$
\begin{aligned}
& \text { М. Ескеева }{ }^{1}, \text { Г. Қортабаева }{ }^{2 *} \\
& { }^{1} \wedge . \text { Н. Гумилев атындағы Еуразия ұлттық университеті, Қазақстан, Нұр-Сұлтан қ. } \\
& { }^{2} \text { Әл-Фараби атындағы Қазақ үлттық университеті, Қазақстан, Алматы к. } \\
& \text { *e-mail: turki_alemi@mail.ru }
\end{aligned}
$$

Түркі мақал-мәтелдеріндегі тәңірлік идеясы

Түркі халықтары бір тамырдан тараса да, наным-сенімдері бірыңғай емес, сол себепті түркі халықтарының Аіни сенімдерін зерттеу күрделі. Аінтанымдық түркітанудың зерттеу парадигмасының аса ауқымдылығын танытады. Әр түрлі діни көзқарастағы түркі халықтарының белгілі бір дінді қабылдауының тарихи-саяси факторларын ғылыми тұрғыдан саралап, тегі бір болса да діни жіктеліске түскен түркілердің ортақ құндылықтар жүйесін айшықтап көрсету, генеалогиялық-тілдік тектестігіне қарай ортақ мүАлеге топтастыру теологиялық түркітанудың стратегиялық бағытын айқындайды. Мақала қазіргі түркілер Аүниетанымындағы Тәңірлік идеясының іздерін түркі мақал-мәтелдерінің мазмұны арқылы анықтауға бағытталған. Жалпытүркілік мифологиялық дүниетаным мен Аіни Аүниетанымның сабақтастығы, өзара ықпалдастығы біртұтас паремиологиялық мағына мен тірек сөздердің семантикалық аясы негізінде сараланады. VI-IX ғасыр түркі жазба ескерткіштері тіліндегі - Тәңірлік идеясы атрибуттарының ислам дінін ұстанатын қазіргі түркі халықтары (қазақ, қарақалпақ, қырғыз, татар) мақал-мәтелдерінің мазмұнынан да көрініс беретіні нақтыланады. Мақал-мәтелдер құрамындағы «Тәңір», «А^^а», «ҚұАай» теонимдерінің синонимАік мағынасы мен ортақ символдық мәндері талданады. Тірек сөздің семантикалық ерекшеліктерінің паремиологиялық мағынаға әсері қарастырылады. Түркі халықтарының Аіни-мифологиялық сенімінің негізін құрайтын Тәңірлік пен ислам дінінің сабақтастығын тілдік бірліктер арқылы зерттеу түркітанудың маңызды проблемасы ретінде өзектеледі.

Түйін сөздер: паремиология, көне түркі жазба ескерткіштері, түркі тілдері, теоним, Тәңірлік илеясы. 


\author{
М. Ескеева ${ }^{1}$, Г. Кортабаева ${ }^{2 *}$ \\ 'Евразийский национальный университет им. А.Н. Гумилева, Казахстан, г. Нур-Султан \\ ${ }^{2}$ Казахский национальный университет имени аль-Фараби, Казахстан, г. Алматы \\ *e-mail: turki_alemi@mail.ru \\ «Тенгрианская» идея в тюркских пословицах и поговорках
}

\begin{abstract}
Хотя тюркские народы имеют одинаковое происхождение, однако их верования не совпадают, поэтому трудно изучать религиозные верования тюркских народов. Религиозно-богословская парадигма тюркологии очень обширна. Стратегическим направлением теологической тюркологии является научный анализ исторических и политических факторов принятия той или иной религии тюркскими народами разных религий, уточнение системы общих ценностей тюрков хотя бы одного религиозного класса, группировка их по генеалогическому и лингвистическому сходству. В статье исследуется идея «Тенгрианства» в мировоззрении современных тюрков через изучение значений тюркских пословиц и поговорок. Преемственность, взаимодействие общетюркского мифологического и религиозного мировоззрений анализируются на основе еАиного паремиологического и семантического значения слов-доминантов. Уточняется, что атрибуты тенгрианской идеи языка тюркских письменных памятников VI-IX веков прослеживаются в содержании пословиц и поговорок современных тюркских народов (казахов, каракалпаков, киргизов, башкиров, татар), исповедующих ислам. Анализируются синонимические значения и общие символические значения теонимов "Тенгри», «А^^ах», «ҚұАай/Бог» в составе пословиц и поговорок. Рассматривается влияние семантических особенностей ключевого/Аоминантного слова на паремиологическое значение. Изучение преемственности «Тенгрианства» и ислама, составляющих основу религиозных и мифологических верований тюркских народов через языковые единицы, актуализируется как важная проблема тюркологии.
\end{abstract}

Ключевые слова: паремиология, Аревнетюркские письменные памятники, тюркские языки, теоним, Тенгрианская идея.

\section{Introduction}

The spiritual culture of the Turks is an integral phenomenon that continuously exists with the history of the people, the improvement of ideological knowledge, changes in everyday life., Proverbs and sayings, a special unity in the world of language, developing and replenishing along with the expansion of the worldview, are a source of information about the life and life of the people, about the system of spiritual, cultural and material values.

The study of the manifestation of the idea of "Tengrism" in the content of paremic units consisting of conceptual knowledge arising from folk wisdom and life experience, the differentiation of traces of ancient faith in the language of modern Turks allows us to identify the features of the formation and development of common Turkic religious values, to determine the continuity, interaction of the mythological worldview and religious worldview. Therefore, the identification of the roots of the Tengrism of the ancient Turks in the ethno-cultural content of modern Turkic paremia is one of the most actual problems in Turkic studies. This, along with linguistic problems related to the nature of the paremiological meaning in the Turkic languages, also contributes to determining the historical foundations of the theological aspect of Turkic studies. In general, the development of the theological aspect of Turkic studies in conjunction with linguistics is one of the most topical issues.

Justification of the topic, goals and objectives

Paremiological units are a rich source of information that accumulates data on the formation and development of the people's worldview, changes in the world of spiritual values. Information about mythological beliefs and religious beliefs in the ethno-cultural content of Turkic proverbs and sayings forms the core of the whole Turkic spiritual world. The main purpose of the article is to distinguish the roots of ancient beliefs in the modern Turkic worldview through the manifestation of the idea of Tengrism in the ethno-cultural content of Turkic proverbs and sayings. To achieve this goal, it is necessary to determine the continuity and interaction of the common Turkic mythological worldview and religious worldview on the basis of the semantic range of paremiological meanings and keywords. The sources of the article are collections of Proverbs and sayings in the Kazakh, Kyrgyz, Bashkir, Tatar, Karakalpak languages belonging to the Kipchak group, as well as texts and transcriptions, translations of ancient Turkic written monuments.

\section{Research methedology}

In the study, methods of description and systematization, traditional comparative-diachronic, 
comparative-synchronous methods of linguistics, semantic, etymological, ethnolinguistic analysis, methods of abstraction, generalization and individualization based on the theory of knowledge are used.

\section{Research background}

The linguistic study of Turkic proverbs and sayings until the end of the twentieth century was mainly carried out in a structural direction. Syntactic structure of Proverbs and sayings in the Turkic languages of the modern Kipchak group, semantic and thematic groups, the nature of paremiological meaning, the main features and common features that distinguish them from phraseology have been studied by resaerchers as I. Kenesbayev, R. Sarsenbayev, A. Kaidar, M. Kopylenko, A. E. Karlinsky, Z. Tarlanov, A. Nurmakhanov, B. Kapasova, H. Karasayev, N. Isanbat, I. Nadirov, K. Mergen etc. In Turkic linguistics, academician I. Kenesbayev was one of the first linguists to distinguish the differences and similarities of proverbs and sayings with phraseological units, considering them as set expressions (Kenesbayev, 1977: 594).

Relevant features of Proverbs and sayings that served as the basis for considering within the framework of phraseology include: stability of syntactic structure and meaning, set expressions in speech and semantic transformation of components. Russian scientists S. G. Gavrin, G. L. Permyakov, V. P. Zhukov, etc.made a great contribution to the development of the theory of paremiology. G. L. Permyakov suggests that the commonality of all regular transformations should be considered in connection with their semiotic nature (Permyakov, 1970: 7).

The distinct features of proverbs and sayings are as followings: figurative meaning of paremiological units expressing conceptual thought; symbolic meaning of lexemes and phrases in the proverbs and saying, which have a literal meaning in a separate; the ability to express expressive-evaluative and emotional connotations; the constant presence in speech determines the special features of Proverbs (Karlinskiy, 1990: 22).

In modern linguistics, proverbs and sayings are considered separately from phraseological unites, but some linguists argue that "proverbs and sayings, like quotations, are an integral part of the lexical and phraseological system of the language, not a fragment, but an independent small artistic text, so it is not a phraseological unit" (Kopylenko, 1978: 82).

Academician A. Kaidar, who based the theoretical concept of the study of Kazakh paremiology in the anthropolinguistic direction, analyzes the processes of formation, development of paremic unity and paremic meaning in the language, features of situational use. Defines the scientific principles of grouping proverbs and sayings, suggests methods and methods of revealing the ethno-cultural and ethnophilosophical background of paremia, internal content aimed at recognizing human existence (Kaydar, 2004).

Ethnolinguistic, linguocultural, linguocognitive features of paremia in modern Kipchak languages were studied by scientists K. Kalybayeva, Sh.Karsybekova, G. Turabayeva, R. Khairullina, Z. Raimgozhina, E. Sozinova, A. Pirniyazova and others.

Definition of the existence of the idea of "Tengrism" in Proverbs and sayings in the languages of the modern Kipchak group of Turkic languages is based on the content of the language units of the Old Turkic inscriptions of the VII-X centuries, which describe the importance of the Tengrism in the worldview and life of the ancient Turks. The idea of the ancient Turkic "Tengrism" was considered in the research of scientists-Turkologists N. Ya.Bichurin, S. G. Klyashtorny, L. P. Potapov, M. Zholdasbekov, K. Sartkozhauly, A. Seidimbek, M. Aji, D. G. Savinov, etc. The phenomenon of the "Tengrism" in Turkic proverbs and sayings was considered from a fragmentary point of view, but was not taken into the object of special research.

\section{Main part}

The content of religion, which is recognized as an ideological mechanism that forms a community of people, organizes common interests, and regulates relations, consists in recognizing socially significant basic values as sacred. The role of religion in culture can be defined as the system-forming factor of each culture" (Gabitov, 2007: 57).

Spiritual and cultural values are based on religious values, the core of vital, social, moral, aesthetic values, and even political values are the priorities of religious values. After all, the basic principles of developed, mature religions are aimed at ensuring a harmonious life of the community, for which moral standards must be observed. The famous German scientist G. Zimmel considers religion from the point of view of the substance of a peaceful existence without conflict, conflict, pointing out the spread of the idea of peacefulness through religion."..he argues that religious values rise to a higher level in the scale of human priority" (Zimmel, 1996: 579).

It is known that mythological beliefs lie in the oldest layers of the history of religious values. This indicates that one of the branches of expression of religious values in the content of Proverbs and say- 
ings of the Kazakh, Kyrgyz, Karakalpak, Bashkir Tatar peoples, adherents of the Islam, is "Tengrism".

The language of the ancient Turkic written monuments is one of the most extensive written sources about the worldview and beliefs of the ancient Turkic peoples about the Lord, natural phenomena, the origin of humanity, human qualities, and the system of cultural and spiritual values inherent in common Turkic existence.

In the Turkic concept, Tengri is a creator, a mysterious force - a symbol of Eternity: "Tengri is an image of the main God, a state of Infinity, equated with the sky in the religious beliefs of the ancient Turks (Gabitov, 2004: 253).

All the distinctive features of Tengri, which are characterized by the language of Turkic written monuments, are derived from the fact that he is perceived in the popular worldview as "the creator of nature and humanity": Üze kök teyri, asra jayiz jer qïlïntuqda ekin ara kisi orlï qïlinmïs «above is the Blue Tengri, below is the Black Earth, between them is the son of man» (Aydarov, 1995: 171).

Although the cult of Sky/Blue is typical for most ancient peoples, the idea of Tengri in the worldview of the Turks, who lived in the VII-IX centuries, is mythological it can be seen that it has evolved from knowledge to religious knowledge. The language of monuments says that they worship not heaven, but only the Lord God, the only creator: Bašlïyì jükündürtim. Tizligig šökürtim. Üze teyri asra jer jarïlqadïq üč(ün) «My head was on the bar, and I folded my knees. Above is the Tengri, below is the Earth for the blessing» (Sartkozha, 2003: 207).

In the texts of the monument, the names kök tepri and tepri are used in the sense of "Lord", while there is no use of the word kök in the sense of "Lord" standing alone. According to the Turkic worldview, Kok (sky or above world) is a place of living of Tengri, the full identity and meaning of the phrase kök teyri is "Heavenly Tengri/Heavenly Tengri". The main features of the concept of Tenir - the creator of the human being, the patron of humanity, the owner of human destiny-are the symbolic and sacred meaning of the concept of heaven.

Every historical, social, military situation, natural phenomena "caused by Tengri": Teyri bulyaqun üčün jayi boldi "Tengri, (I) was the enemy of (us) for being exposed to the Earth" (Sartkoja, 2003: 117).

In the text of monuments, there are also sentences that describe the fact that all evil and failure are caused not by the will of God, but by the fault of humanity itself: Begleri, bodunï tüzsiz üčün, tabyač bodun tebligin kürlig üčün, armaqčisïn üčün, inili-ečüli kek šürtukin üčün, begli bodunli $\gamma$ jonašürtuqïn üčün türk bodun illedük ilin ïčïnu iadmïs "the Turkic people lost their country because of the injustice of their people, because of their belief in their the deceit of the tabgach (a tribe) people, because of accepting thier lie, because of the conflict of brothers, because of the hostility of the Bek people (aristocratic people)" (Aydarov, 1995: 173).

This indicates that Tengri, which arose from the simple mythological worldview of the ancient Turks, is somewhat interrelated with the true worldview. It can be seen that the Tengrism, based on a religious and mythological believes, became the basis of Turkic patriotism, which became the basis of the idea of the eternal country, which embodied the story of the people, unity of the people in real life. The tradition of accepting Kagan as the «messenger of Tengri», based on the idea of Tengri in the worldview of the ancient Turks, not only preserved the integrity of the political and social structure of the country, but also contributed to strengthening internal unity, became the basis for developing the strategic and tactical potential of the military system, establishing diplomatic relations with neighboring states.

The traces of religious and mythological edification of the ancient Turks continue from generation to generation through the common Turkic consciousness and are reflected in the language of modern Turkic peoples who adhere to various religious beliefs. The ancient Turkic belief Tengrism is also found in the paremiological system of the Kipchak group Turkic languages. The content of Proverbs and sayings about religious values in the languages of the modern Kipchak group includes death and life, good and bad qualities, education of generations, everyday life, social relations, attitudes to the environment, nature, etc. he describes all the circumstances of human life in connection with the creator.

In other words, if it describes religious values in direct meaning, it can also determine the essence of social, moral, and aesthetic values in some situational use. This characterizes the special feature of the paremiological meaning built on the figurative meaning. The meaning of semas in the content of the dominant word are of great importance in determining the semantic meaning of proverbs and sayings. Instead of the reference word in the composition of phraseologisms, the term "core word" (Kenesbayev, 1977: 611) is also used. The main prop words of proverbs and sayings related to religious belief are the theonyms Tengri, Allah, God, Creator etc., the mythonyms Umai, Kudu, etc. As well as not participating in the main teonim-AO, the idea of consolidating all Muslims around the common belief that can give couples a universal binary content (soul 
$\leftrightarrow$ body, life $\leftrightarrow$ death, earth $\leftrightarrow$ sky, earth $\leftrightarrow$ water, fire $\leftrightarrow$ water, white $\leftrightarrow$ black, day $\leftrightarrow$ night) in the framework of lexical semantic can be neutral.

The main dominant word in Turkic proverbs and sayings about the Tengrism, which forms a paremiological model of religious values and serves as a symbol of the true feature of the religious worldview, is the theonym Tengri. In Kazakh, tengri is "religious word which means 1. God, Allah, Almighty; 2.Almighty, Lord of power" (Explanatory dictionary of the Kazakh language, 2008: 791).

In other Kipchak Turkic languages, the main and symbolic meanings of the Tengri token are fully preserved. The reference word defines the literal meaning of Proverbs, that is, the initial or main meaning of the syntactic structure. The reference words of each component of Proverbs made up of complex sentences are mostly different. Proverbs and sayings with the theonym Tengri in the modern Kipchak languages are classified into several groups that contain the qualitative properties of Tengri in their literal meaning. And characterizes the life positions of the population, which are determined in accordance with the unified paremic worldview and spiritual and cultural values, life experience, which determines the situational application.

Tengri - Creator: the body is amanat (something sacred that's given to save) of the soul, the soul is amanat of the Tengri (Golden Book of Kazakh Proverbs, 2018: 386) this paremia, which describes the Universal worldview that when the human body is created from the earth/soil, the soul is created by the heavenly Tengri, when it dies, the body goes back to the Mother Earth, the soul goes back to the Lord, confirming the truth of "one death to the core", the ability to live this life meaningfully, "without abuse of the Amanat".

As well as, in Kaz. the proverb "A person's bone is given by his mother, blood by his father and soul is given by Tengri" (Golden Book of Kazakh proverbs and sayings, 2018: 38) also emphasizes the place of mother and father in the upbringing of a child, instills in the consciousness the quality of Tengri's creation, characterizes the importance of respect for parents.

The Kazakh proverb Qunanyn Qudaiynday, tanasyn Tanirindei koredi (The Golden Book of Kazakh Proverbs and Sayings, 2018: 380) describes people who see themselves and their own as better than others. The idea of the proverb indicating that people of bad character and with bad habits gather in groups, as well as advocating others to stay away from this sorry lot and strive for goodness Tanir atkandy Tanir atkan maqtaidy (The Golden Book of
Kazakh Proverbs and Sayings, 2018: 384) to some extent coincides with the proverb Uryny ury alystan tanidy, Apama zhezdem sai (It takes one to spot one). Mechkai - Tanrenen ubyry (Nakiy, 2010: 763) condemning insatiability and unsatisfaction comes from the Tatar proverb "Meshkei - Tanirdin obyry". According to Tengrism, breaking promises and lying are a sign of irresponsibility and obscenity: Tanrega aitkan, kiramatka birgan (Nakiy, 2010: 762). Idleness is one of the worst qualities in a person. The proverbs and sayings aiming to demolish this bad habit include the Kazakh Bekerden beker zhatqannan Tanir bezer (The Golden Book of Kazakh Proverbs and Sayings, 2018: 19), its variant Bekerden Tanirim bezer (The Golden Book of Kazakh Proverbs and Sayings, 2018: 368), the Karakalpak equivalent Tentekten taniri biyzar (Karakalpak Folklore, 2015: 84) and the Bashkir version Tik iorogandan Tanre bizer, as in "Idleness is the beginning of all sin". One of the Kazakh proverbs that promotes the need to strive instead of succumbing to laziness is Berer Tanirim talap qylsan, Tuk tappaidy qarap zhatqan (The Golden Book of Kazakh Proverbs and Sayings, 2018: 205). One of the most inhumane habits is envy. The semantics of a Bashkir proverb Tanre malyn shaitan qyzgangan "Tanri malyn shaitan qyzgangan", its variant Tanre ashyn shaitan qyzgangan "Tanri asyn shaitan qyzgangan" (The devil envies God's meal) imply that it is a bad habit to envy the wealth of others or their opportunities, while the need to support and strive for such achievements is what is encouraged to foster. A Kyrgyz proverb Ten zhegendi Tenirim cuiet, ashyq zhegendin kepini kyiot (Ibragimov, 2008: 528) calls to be wary of greed and to be generous with others.

The theonym Tengri in the Kipchak language group describes the life position of our ancestors who aspired to maintain the order of social relations and thus ensuring the harmonious development of society. For example, the parable of the Kazakh Korshi haqysy - Tanir aqysy (The Golden Book of Kazakh Proverbs and Sayings, 2018: 14), its variation Qonaqasy - Tanir aqysy (The Golden Book of Kazakh Proverbs and Sayings, 2018: 136) and the Bashkir version Kurshe haqy - Tanre haqy and its variant $I r$ haky - Tanre haky promotes the establishment of a respectful relationship with your neighbour. Among the proverbs and sayings that characterize Tengri as the main mechanism for strengthening the unity and solidarity of a nation, ancient Turkic knowledge is firmly established in the worldview of modern Turkic peoples as is evident from their proverbs and sayings: Toby birdin - Taniri bir (The Golden Book of Kazakh Proverbs and Sayings, 2018: 20) in Kazakh 
and Tentushtin Teniri bir (Ibragimov, 2008: 529) in Kyrgyz. These proverbs share the same meaning with Kemedeginin zhany bir. The moral principle of "The minority being subject to the majority" can be found in the Bashkir languange: Ike keshe - ber keshenin tanrehe, as in "Two people are one man's Tengri”.

In accordance with the changes in the religious position of the Turks in modern Turkic languages, tangir/tangiri, tangre, tangir/tangiri, tengir/tengiri, tengir/tengri, tegri, tigir, dair, tura, tenger/tengeri and other phonetic variants that use the lexeme tengri of Altai are replaced with the Arabic theonym Allah and Persian qudai. However, the ancient word has been preserved as part of phraseology and pareomia, toponyms and anthroponyms. It is also used as a synonym for the words Allah, Allah Almighty and qudai (God, the Lord/the Creator).

God "religious. The creator of the whole universe, the Most High, the Almighty; 2. Figur. The strongest, the ruler, the chief" (Explanatory dictionary of the Kazakh language, 2008: 532).

Ideas about the truth and omnipotence of God serve as a base for the semantic meaning of proverbs and sayings with the God lexeme. For example, in Karakalpak: Kisinin bergeni - keuillik, Qudaidyn bergeni - toiymlyq (Karakalpak folklore, 2015: 109); Ushyp keldim Zhaiyqtan, Qudai qosty gaiyptan (Karakalpak folklore, 2015: 79); Qudaidan soragannyn buiiri shygar (Karakalpak folklore, 2015: 94); Qudai saldy bir isti, Basy amanlar kulisti (Karakalpak folklore, 2015: 98); Qudaidyn aty kop (Karakalpak folklore, 2015: 94); Qudai malyndy alsa da, Peilindi almasyn (Karakalpak folklore, 2015: 109); Qudaiyna syiynsan syiyn, Eshegindi bekkem baila (Karakalpak folklore, 2015: 93); Qudaiy bergen qulyna, shygaryp qoiar zholyna. Qudaiy bermegen qulyna, izlese tabylmas pulyna (Karakalpak folklore, 2015: 94); Baidyn zhany kuise, Qudaidy qargaidy, Zharlynyn zhany kuise, Zharagyn zhamanlaidy (Karakalpak folklore, 2015: 118); Qudaidan ake tilesen de, ake bermes (Karakalpak folklore, 2015: 98) etc.

Due to the fact that the Turks and Persians have long lived in neighbouring regions, the Persian word qudai entered Turkic languages earlier than the Arabic Allah. Its active use in the Kazakh language and abundance of the range of paroemia in which the theonym is involved, as well as its frequent occurrence in folklore led to qudai being relevant up until the X century. Qudai lexeme is also used as quda in colloquial speech: qudanyn qudyreti. The complex theonym qudai tagala is formed by the same principle as the phrase Allah tagala. The
Persian word qudai and the Arabic tagala used as a pleonasm acquires a semantic tone that reinforces God's omnipotence.

Alla/Allah "religious. God, creator" (Explanatory dictionary of the Kazakh language, 2008: 42). In the languages of the modern Kipchak group, paroemia with theonym Allah is also often used. For example, the Tatar Allaga yshan, usen qymshan; Allaga yshanyp suga toshma, ioza belsan tosh; Alladan kotken bush qakyr, uzene yshangan yaulap alyr (Nakiy, 2010: 769), and other proverbs describe that all human achievements and failures depend not only on Allah, but also on oneself. The loaning of the lexeme Allah is the result of a linguistic and cultural connection formed in the $\mathrm{X}$ century, directly related to the spread of Islam to the Turks. A proverb describing the peculiarities and spirit of Kazakh life Shalqaiganga shalqai, ol - Allanyn uly emes, Enkeigenge enkei, ol - atannyn quly emes contains the idea of obedience to the omnipotence of Allah. Special qualities of the Lord in the worldview of the Turkic peoples who profess Islam are grouped into the content of theonyms Tanir, Qudai, Alla and serve as a base for proverbs describing spiritual and cultural vales in the language.

\section{Results and discussion}

The concept of Tengri in the content of modern Turkic proverbs and sayings is preserved in the language of religious and mythological beliefs of the ancient Turks, which is caused by the desire to learn more about the universe, the environment, oneself and creation in general. Since the expansion of the national worldview is based on spiritual principles, the religious beliefs of the Turkic peoples also originate from ancient spiritual and religious values. The concept of Tengri, passed down from generation to generation, continues from "the religious and mythological worldview of the Huns who lived in the last hundred years BC, the Turkic-Mongol tribes that inhabited Central Asia in the first centuries BC" (Bichurin, 1960: 49), then the Late Middle Ages to modern Turks whose religious values have changed. The famous historian and ethnographer L.P. Potapov also states that the roots of the Turkic "Tengri" faith are very deep and consistent (Potapov, 1973: 265). In the context of the content of proverbs and sayings of the Kazakh, Kyrgyz, Karakalpak, Tatar and Bashkir peoples who profess Islam, the signs of the idea of Tengri fully confirm that spiritual values are preserved in the memory of the people through the continuity of generations.

According to the mythological belief of the Turks, Tengri is the only Creator, while Kagan is a gift to the 
people from Tengri. S.G. Klyashtorny explains the ancient beliefs of the Turks through the functional image of Tengri: "Tengri rules both the universe and the fate of man: joy and sorrow inherent in the fate of mankind are sent from Tengri; he gives power, wisdom to the chagans (Kagan) and chagans to people; punishes those who object to the chagans; he directs state and military affairs by giving orders to the chagans" (Klyashtornyy, 1981: 132).

The concept of Tengri in the knowledge of the Turkic peoples is distinguished by its stability, mystery and omnipotence. Ethnographer A. Seidimbek states that Tengri is a mysterious phenomenon for the Turks: "On the basis of actual postulates of Tengri beliefs, the idea of communication with nature is established. Tengri in the perception of nomads... (is) the object of eternal knowledge and, at the same, time the infinite cosmos" (Seydimbek, 1997: 89). The content-idea, that reflects the religious beliefs established in the semantic framework of modern Turkic paroemia, also includes moral, ethical, aesthetic and environmental principles aimed at ensuring a harmonious life of the population in society.

\section{Conclusion}

Worldview is recognized as a system of spiritual and practical assimilation of truth, while language serves as the basis for the formation of a system of concepts recognized in consciousness, external forms of worldview as the embodiment of knowledge in reality, and serves as a tool of long-term generational continuity of knowledge. Incomplete or generalized information about the truth that has emerged in the consciousness of humanity, which exists between real objects consisting of objects and phenomena, events and actions, relationships, passes through the human mind through cognitive processes, and conceptual judgments are established that compensate for intellectual, spiritual, cultural and social needs.
This characterizes the fact that a representative of a particular ethnic group lives not only in the factual world of truth, but also in the ideal world created by oneself and one's community. That is, the language of an ethnic group, which expresses the individuality of a community that speaks a certain language, the facets of its ethnic reality, reflects universal conceptual ideas from the perspective of the worldview and truth of its ethnic group. This also applies to the semantic content of the paroemia, which has preserved traces of the Tengri faith, indicating the deep history of the religious worldview of the Turkic peoples.

The semantic wording of proverbs and sayings related to the Tengri faith in the modern Kipchak languages group of adherents of Islam to a certain extent coincides with the content of Islamic theses related to the properties of Allah, respect for parents, education of generations, right conduct and healthy lifestyle, regulation of relations between people, etc. This indicates that the paroemia, which have preserved traces of the idea of Tengri in the languages of the Kipchak group, form linguistic indicators that characterize the continuity and harmony between the ancient religious faith of the Turks and the current religion of Islam.

Modern paroemiologies related to the Tengri faith in the Kazakh, Karakalpak, Kyrgyz, Tatar and Bashkir languages included in the Kipchak group are among the symbols that form the linguistic model of religious values and are recognized as language units that determine the manifestation of the religious worldview. The semantic content of proverbs and sayings describing the Tengri faith, which the ancestors of the Turks adhered to, is derived from the interests of purifying the spiritual world of a person, putting society on a harmonious path, getting rid of bad habits and regulating social relations.

The article was carried out within the framework of the scientific project of grant funding AP08856427.

\section{References}

Айдаров Ғ. (1995) Күлтегін ескерткіші. - Алматы: Ана тілі. - 232.

Бичурин Н. Я. (1960) Собрание сведении о народах, обитавших в Средней Азии в древние времена. Том. 2. - М-Л.: Издательство АН СССР. - 362.

Ғабитов Т., Мүтәліпов Ж., Құлсариева А., Ибекеева С. (2007) Мәдениеттану. - Алматы: Раритет. - 416.

Зиммель Г. К (1996) социологии религии//Избранное в 2-х томах. Т.1. Философия культуры. - М.: Юрист. - 680.

Ибрагимов М. (2008) Кыргыз макал, лакап, учкул сөздөру. - Бишкек: ST.art. - 640.

Карлинский А.Е. (1990) Основы теории взаимодействия языков. КазССР, Ин-т языкознания. - Алма-Ата: Ғылым. - 160. Кеңесбаев I. (1977) Қазақ тілінің фразеологиялық сөздігі. - Алматы: Ғылым. - 711.

Кляшторный С.Г. (1981) Мифологические сюжеты в древнетюркских памятниках // Тюркологический сборник. - М.: Наука. - 131-137.

Копыленко М.М., Попова З.Д. (1978) Очерки по общей фразеологии. - Воронеж: Издательство Воронежского университета. - 141. 
Қазақ тілінің түсіндірме сөздігі. (2008). - Алматы: Дайк-Пресс. - 968.

Қазақ мақал-мәтелдерінің алтын кітабы. (2018). - Алматы: Аруна. - 632.

Қайдар Ә.Т. (2004) Халық даналығы. - Алматы: Толағай. - 560.

Қарақалпақ фольклоры (2015) Көп томдық. Т. 88. - Нөкис: Илим. - 355.

Мәдени-философиялық энциклопедиялық сөздік (2004) / Құрастырғандар: Т. Ғабитов және т.б. - Алматы: Раритет. -320.

Нәкый И. (2010) Татар халық мәкальләре. Т. ІІІ. - Казан: Татар. Кит. Нәшр. - 799.

Потапов Л.П. (1973) Умай - божество древних тюрков в свете этнографических данных // Тюркологический сборник //

А.Н. Кононов (ответственный редактор), С.Г. Кляшторный, Ю.А. Петросян, С.С. Цельникер. - М.: Наука. -412.

Пермяков Г.Л. (1970) От поговорки до сказки (Заметки по общей теории клише). - М.: Восточная литература. -240.

Сартқожа Қ. (2003) Орхон мұралары. - Астана: Күлтегін. - 392.

Сейдімбек А. (1997) Қазақ әлемі. - Алматы: Санат. - 464.

\section{References}

Aydarov G. (1995) Kultegin yeskertkishi [Kultegin's monument] (Almaty: Ana tili, 232) (in Kazakh).

Bichurin N. YA. (1960) Sobraniye svedenii o narodakh, obitavshikh v Sredney Azii v drevniye vremena. [Collection of information about the people who inhabited Central Asia in ancient times. Tom. 2.] (Moskva-Leningrad: Izdatelstvo AN USSR. 362) (in Russian).

Gabitov T., Mutalipov Zh., Kulsariyeva A., Iybekova S. (2007) Madeniyettanu. [Culturology] (Almaty: Raritet, , 416) (in Kazakh).

Ibragimov M. (2008) Kyrgyz makal, lakap, uchkul sozdoru [Kyrgyz proverbs, nicknames, catchphrases] (Bishkek: ST.art, 640) (In Kyrgyz).

Karakalpak folklore (2015) Kop tomlyk. 88 T. [Karakalpak folklore. Multivolume] (Nokis: Ilim, 355) (In Karakalpak).

Karlinskiy A.E (1990) Osnovy teorii vzaymodeystviya yazykov [Fundamentals of the theory of language interaction] (AlmaAta: Gylym.160) (in Russian).

Kaydar A.T. (2004) Khalyk danalygy [The wisdom of the people] (Almaty: Tolagay.560) (in Kazakh).

Kazak tilinin tusindirme sozdigi (2008) [Explanatory dictionary of the Kazakh language] (Almaty: Dayk-Press, 968) (in Kazakh).

Kazakh makal-matelderinin altyn kitaby (2018) [The golden book of Kazakh proverbs] (Almaty: Aruna, 632) (in Kazakh).

Kenesbayev I. (1977) Kazakh tilinin frazeologiyalyk sozdigi [Phraseological dictionary of the Kazakh language] (Almaty: Gylym. 711.) (in Kazakh).

Klyashtornyy S.G. (1981) Mifologicheskiye syuzhety v drevnetyurkskikh pamyatnikakh//Tyurkologicheskiy sbornik [Mythological plots in ancient Türkic monuments //Türkological collection.] (Moskva: Nauka, 131-137) (in Russian).

Kopylenko M.M., Popova Z.D. (1978) Ocherki po obshey frazeologii [Essays on general phraseology] (Voronej: Izdatelstvo Voronejskogo universiteta. 141) (in Russian).

Gabitov T. jane t.b. qurast. Madeni-filosofiyalıq enciklopediyalıq sozdik (2004) [Cultural and philosophical encyclopedic dictionary. Ed. Gabitov T. and others] (Almati: Raritet, 320) (in Kazakh).

Nakiy I. (2010) Tatar khaiyk makallare. III T. (Kazan: Taтar. Kit. Nashr. 799) (in Tatar).

Permyakov G,L. (1970) Ot pogovorki do skazki (Zametki po obshey teorii klishe) [From sayings to fairy tales (Notes on general theory of cliches)] (Moskva: Vostochnaya literatura. 240) (in Russian).

Potapov L. P. (1973) Umay - bozhestvo drevnikh tyurkov v svete etnograficheskikh dannykh //Tyurkologicheskiy sbornik// A.N.Kononov (otvetstvennyy redaktor), S.G.Klyashtorniy, YU.A.Petrosyan, S.S.Tselniker [Umai - the deity of the ancient Türks in the light of ethnographic data] (Moskva: Nauka, 412 p.) (in Russian).

Sartkozha Kh. (2003) Orkhon muralary [Orkhon monuments] (Astana: Kultegin, 392) (in Kazakh).

Seydimbek A. (1997) Qazaq alemi. [The world of the Kazakhs] (Almaty: Sanat, 464) (in Kazakh).

Zimmel G.K. (1996) K sotsiologii religii// Izbrannoe v 2-kh tomakh. T.1.Filosofia kultury [To the sociology of religion // Selected works in 2 volumes. T.1 Philosophy of Culture] (Moskva: Iurist, 680) (in Russian). 